International Journal of Dentistry and Oral Science (JDOS)

ISSN: 2377-8075

\title{
Caries Management: A Journey between Black's principals and Minimally Invasive Concepts
}

Hamdi H. Hamama ${ }^{1 *}$, Cynthia K.Yiu ${ }^{2}$, Michael F. Burrow ${ }^{3}$

Review Article

${ }^{1}$ Clinical Assistant Professor, Aesthetic and Restorative Dentistry Department, Faculty of Dentistry, Mansoura University, Egypt.

${ }^{2}$ Clinical Professor, Paediatric Dentistry and Orthodontics Department, Faculty of Dentistry, The University of Hong Kong, Hong Kong SAR, China.

${ }^{3}$ Professor and Chair of Biomaterials, Melbourne Dental School, Australia.

\section{Abstract}

Dental caries is a multifactorial microbial disease that affects tooth hard tissue leading to destruction of its mineral and organic components. The current work reviewed the development of caries assessment methods and excavation concepts in the past two centuries. In the late ninetieth century, G.V. Black introduced a classification of dental caries, as well as established the principals of tooth preparation, based on his understanding of the nature of the disease. However, due to the great development of dental materials and caries detection methods, most of Black's principals are no longer valid nowadays. In light of the minimal invasive philosophy, several new caries excavation concepts were introduced. These concepts converts 'old' Black's caries excavation concept of "extension for prevention" to "prevention of extension". Since 2000 the concepts of caries excavation have greatly changed due to the popularity of the "partial caries removal' concept. As an example of this new 'conservative' vision, the "Fédération Dentaire Internationale" (FDI) (World Dental Federation) approved the atraumatic restorative technique (ART) as one of the caries excavation methods in 2002.

Keywords: Caries; Extension For Prevention; Caries Excavation; Minimally Invasive Technique; Atraumatic Restorative Technique.

\section{*Corresponding Author:}

Dr. Hamdi Hosni Hamdan Hamama,

Clinical Assistant Professor, Aesthetic and Restorative Dentistry Department, Faculty of Dentistry, Mansoura University, Po (box) 35516, Egypt. Tel: +201145177662

E-mail: hamdy@connect.hku.hk

Received: June 24, 2015

Accepted: July 29, 2015

Published: August 03, 2015

Citation: Hamdi H. Hamama, Cynthia K.Yiu, Michael F. Burrow (2015) Caries Management: A Journey between Black's principals and Minimally Invasive Concepts. Int J Dentistry Oral Sci. 2(8), 120-125. doi: http:// dx.doi.org/10.19070/2377-8075-1500026

Copyright: Hamdi H. Hamama ${ }^{\circ}$ 2015. This is an open-access article distributed under the terms of the Creative Commons Attribution License, which permits unrestricted use, distribution and reproduction in any medium, provided the original author and source are credited.

\section{Dental Caries}

Caries is from the Latin word that means "rottenness". Dental caries is defined as "an infectious microbiological disease of the teeth that results in localized dissolution and destruction of the calcified tissue" [1]. In the early nineteenth century, many theories were developed to explain the aetiology of dental caries; the psychic condition theory (Ancient Greeks), dental gangrene theory (Bell,1825), fungi theory (Leber and Rottenstein, 1867), and chemical theory (Magitot, 1878). However, most of them were rejected [2]. In 1932, Williams [2] isolated the bacterial films which covered the carious enamel and he referred to it as "bacte- rial plaque". He assumed that caries was initiated by the fermentation of organic materials, which were present inside these films [2]. Williams findings introduced the most plausible explanation of the occurrence of dental caries, which is known as the "dental plaque theory". This theory correlated the occurrence of dental caries with the presence of dental plaque [1].

Dental plaque(biofilm) is defined as "a soft thin film of food debris, mucin and epithelial cells that adheres to the tooth surface, providing the medium for the growth of various bacterial species" [1]. However, the presence of dental plaque alone doesnot cause dental caries. This has led to a new modification of the dental plaque theory, which is now known as the "Specific dental plaque hypothesis" [3]. This theory considers dental plaque as an etiological factor for dental caries when pathogenic bacteria are also present.

The term "cariogenic bacteria" refers to certain pathogenic microorganisms, which have the ability to ferment the carbohydrates and produce acids as a by-product [1]. Those acids can dissolve dental hard tissues; while the accumulated plaque layers act as an insulator protecting the pathogenic organisms from the buffering, antibacterial and washing actions of saliva [1]. Much evidence supports the specific dental plaque hypothesis; for example the absence of dental caries in un-erupted and germ-free animal's teeth [1]. Furthermore, many studies reported the presence of cariogenic bacteria within oral biofilms, which covered active carious lesions.

\section{The cariogenic microorganisms within oral biofilms}

The cariogenic bacterial species within the dental plaque are 
mainly streptococci, Lactobacilli and Actinomyces. The Streptococci species are S.mutans, S. circetus, S. rattus, S. ferus, S. sanguis and S. sobrinus [4]. The cariogenic lactobacilli species are L. casei, L. acidophilus, L. plantarum, and L. salivarius. The Actinomyces group includes $A$. naeslundii, $A$. viscosus, $A$. israelii, $A$. meyeri, and $A$. odontolyticus [4]. In spite of the capability of Actinomyces to produce acids, they are considered as a bi-functional microorganism due to its great role in the maturation of dental plaque.

\section{Pathogenesis of dental caries}

An organic $10 \mu \mathrm{m}$ thick, cell-free, film called "acquired enamel pellicle" mainly consisting of salivary proteins adsorbs to newly erupted or recently cleaned tooth surfaces $[1,5]$. One hour later, specific highly adherent bacteria (streptococcus sanguis, Actinomyces naeslundii, and Actinomyces viscosus) invade the pellicle [1, 5]. Then, the Actinomyces starts to mature and help other poorly adhesive bacteria to colonize and accumulate within the successive biofilm layers. Due to a lack of oxygen in deep biofilm layers, bacteria start to metabolize carbohydrates through the glycolytic pathways producing lactic acid as a by-product, which consequently decreases the $\mathrm{pH}$ level within the biofilm. When the $\mathrm{pH}$ drops below the critical level, the tooth starts to demineralize to buffer the high acidic environment by losing its calcium and phosphate ions [1]. This process is considered as the trigger point of the destruction and dissolution of dental hard tissues. This procedure is initiated in the enamel and when left without treatment, it may lead to complete loss of the enamel matrix. Accordingly, dentine will be directly exposed to the action of bacterial enzymes [13]. Unlike enamel, the acidity of the biofilms can easily demineralize calcium from dentine, which leads to exposure of the collagen framework to the proteolytic enzymes produced by the bacteria [13]. However, the immediate destruction of the tissue does not occur in dentine compared to that in enamel lesions [6]. The persistence of the cariogenic factors for a long time will result in permanent damage of the collagen fibres (denatured collagen) [13]. In these circumstances, when the aetiological factors are eradicated and a favorable environment of remineralization is maintained, the softened dentine could be preserved and remineralization of partially-demineralized collagen can take place [5-8].

\section{Histopathology of dentine caries}

Successful treatment of dentine caries depends on a good understanding of the nature of the lesion. The histological features are associated with the progression rate of the lesion; slow, moderate and rapidly progressing caries. Slowly progressing carious lesions are characterized by continuous demineralization and remineralization cycles, which results in deposition of "whitlockite" ${ }^{\text {"* }}$ crystals into dentinal tubule lumens until they become fully obliterated leading to "sclerotic dentine" [5, 9]. While in the moderately progressing carious lesions, odontoblasts undergo a fatty degeneration process, which leads to characteristic histological phenomenon named as "dead tracts" (empty dentinal tubules) [5]. Furthermore, in active carious sites (rapidly progressing), the pulp responds to the external stimulus and starts to lay down a reactive type of dentine referred to as "reparative dentine".

Histologically, dentine caries consists of five zones; normal, the sub-transparent, transparent, the turbid and infected dentine zones respectively [1]. The "normal" zone is the deepest layer of the lesion, in which, the dentinal tubules are un-altered with no crystal formation or bacteria present in the lumen. The next zone is the subtransparent layer, which is characterized by demineralization of the intertubular dentine, deposition of fine crystals "whitlockite" in the tubule lumen and absence of bacteria inside the tubules. The next zone is the transparent dentine, which is similar to the sub-transparent dentine, but the dentinal tubule lumen contains large crystals due to excess demineralization of the intertubular dentine, however, there is no destruction of the collagen fibres, and no bacterial penetration. Following the transparent layer is the turbid layer, which shows dentinal tubule destruction, denaturation of collagen fibres and marked bacterial infiltration. The most superficial zone is the infected dentine, which is characterized by complete decomposition of the dentine (complete absence of mineral and collagen content) with significant bacterial infiltration. These features of dentine caries introduced two important terms used in restorative dentistry, namely, "caries-infected" and "caries-affected" dentine [6]. The "caries-affected" (inner carious) dentine is the demineralized dentine that is not invaded by bacteria and includes sub-transparent, transparent and turbid dentine zones $[1,6]$. The bacterially invaded dentine is called "caries-infected" (outer carious) dentine which includes the infected dentine zone and a very small area of the turbid zone $[1,6]$. Fusayama [6] reported that one of the main differences between the two layers of dentine caries is the collagen structure; collagen in the caries-infected dentine zone is characterized by irreversible destruction of cross-linking sites. Also, the cross-banding structure of collagen is well-maintained in caries-affected dentine regions, in comparison with caries-infected dentine regions [6].

\section{Caries-disclosing dyes and its relevance to Fusayama's his- tological findings}

The clinical differentiation between "caries-affected" and "cariesinfected" dentine is one of the most difficult challenges encountered clinically $[6,10]$. Conventional means of detection are based on visual and the tactile sensation; [1] however, these methods are subjective and variable amongst practitioners. In 1983, an attempt was made to differentiate between the two layers of dentine caries using a chemical dye named as "caries-disclosing dye" or "caries detector". This was theoretically based on the histological features of dentine caries observed by Fusayama [6, 11].

Caries-disclosing dyes were introduced to overcome the drawbacks of visual and tactile methods. Kuboki et al. [11] reported that caries-disclosing dyes could only stain the denaturated collagen fibres; however, the dyes could not stain either sound dentine powder or demineralized intact collagen. The first caries-disclosing dye consisted of $0.5 \%$ basic fuchsin in a propylene glycol base $[12,13]$. Radiographic examination and laboratory study outcomes showed that this formula was not efficient in differentiating both dentine-caries layers [14]. Due to the carcinogenicity of fuchsin (magenta), a new generation of caries detectors was introduced $[6,15,16]$. The replacement of fuchsin by $1 \%$ acid-red in a propylene glycol base was the most characteristic feature of these newer caries detector dyes [17]. However, some authors showed disagreement with the efficiency of this type of caries-disclosing dye, and reported that it can give false positive results $[13,18,19]$. This consequently led to over cutting of healthy dental tissues 
(over preparation) $[13,18,19]$. To solve this dilemma, some authors recommended leaving the lightly-stained (pale pink) tissues, because this represents the caries-affected dentine [13, 20]. Moreover, these false positive results may be attributed to the use of low molecular weight propylene glycol (76 MW) [21]. Therefore, in the next generation, the propylene glycol (76 MW) was replaced by a high molecular weight poly-propylene glycol (300MW) base $[13,21]$. Later on, two studies [21, 22] compared laser flourescence recording from the DIAGNOdent $(\mathrm{KaVo}$, Bibberach, Germany) of residual dentine following caries removal guided with both propylene glycol-based dyes and they concluded that the poly-propylene glycol-based dye is much more conservative of tooth structure than the original low molecular weight propylene glycol dye.

Classifications of dental caries based on the histologic features of carious tissues and in light of the minimally invasive philosophy

Mount classification: In the early twentieth century, G.V Black established the conventional classification of dental caries lesions, based on the most common carious lesion sites and the available restorative materials [23]. In 1998, Mount [24] introduced a new classification based on the recent minimally invasive concepts and contemporary restorative techniques. Mount demonstrated that any carious lesion can be identified by using two parameters; the affected site and stage (size) of the lesion [24, 25]. Based on Mount's classification, caries can affect the following sites, site 1; pits, fissures and enamel defects on the exposed enamel surface of all teeth, site 2; approximal enamel surfaces immediately cervical to the contact areas, site 3; the cervical one-third of the crown or the exposed roots [25]. Each of the previously mentioned sites can be further classified based on the size of the lesion into 5 stages; stage 0 , incipient lesions, which can be treated by the medical model of treatment (remineralization), stage 1 , minimal cavities involving the dentine just beyond the level of treatment by the remineralization methods alone, stage 2 , moderate cavities involving dentine, while the remaining surrounding enamel is sound, well supported and not likely to fail under normal occlusal load, stage 3 , is an enlarged cavity beyond the moderate one and the remaining tooth structure is likely to fail under occlusal function, stage 4 , is an extensive cavity with bulk loss of tooth structure [25]. Although Mount's classification is based on the recent minimally invasive concepts, it has not been widely adopted because it seems to be more descriptive and the boundaries between the stages are not clearly elaborated.

International Caries Detection and Assessment System (IC$\boldsymbol{D A S})$ : A new set of standardized clinical visual criteria for detection of carious lesions, referred to as International Caries Detection and Assessment System (ICDAS), was introduced in 2003 [26]. The rationale of the ICDAS system was to create a standardized caries detection system following the World Health Organization (WHO) guidelines and based on the most up-to-date Caries Research studies [26]. The main objective of this system was to unify the measuring criteria of caries activity among epidemiological and clinical studies [26]. Also, it was designed to detect caries on both enamel and dentine surfaces, as well as, coronal and root surfaces [26].

The ICDAS system was introduced in 2003, and modified in 2005, at the ICDAS workshop in Baltimoreto ICDAS-II [27, 28]. The full code two-digit system is commonly used in the epidemio- logical studies. The first digit identifies the restorative status of the tooth; unrestored, restored or sealed; while, the second digit describes the severity of the lesion (cavitated or non-cavitated) and its activity (arrested or active) [35]. It has been recommended to use a ball-end explorer for diagnosis of carious lesions, to avoid damage of the incipient caries regions [27]. Although the original ICDAS-II system consists of 6 codes, Ricketts et al. [29] have suggested to reduce them to 4 , based on the histological findings of Ekstrand et al. [30] and Lussi et al., [31] for simplifying the clinical use of the system. According to the most updated ICDAS-II criteria [32], caries can be classified into three stages; early-detected (scores 1 and 2), established (scores 3 and 4) and severe (scores 5 and 6), and these stages are referred to as ICDAS's International Caries Classification and Management System (ICCMS).

\section{Caries Excavation Concepts}

\section{Extension for prevention}

Caries excavation concepts were established at the end of the nineteenth century. The first published work was by Webb [33] in 1883, who mentioned in his textbook that "every cavity must be so prepared that no decalcified tissue remains, except where there be a little discolored dentine near the pulp, and that should be left for its protection". Webb supported the extension of the preparation into the contact-free "self-cleansing" areas to avoid the accumulation of food, especially on the proximal surface and he called this process "prevention of extension of decay" [33]. In 1891, Black [34] introduced the term "extension for prevention", and then he described it in his following publications as: "In no case should any decayed and softened material be left. It is better to expose the pulp of the tooth than leave it covered only with softened dentine" $[2,35]$. Although, extension for prevention was a widely accepted concept at this period [36-38], some authors raised many arguments about it, seeking more conservation of the tooth structure to achieve better aesthetics by reducing the display of metallic restorations [39, 40].

\section{Extension for retention}

As a result of the inferior mechanical properties of the metallic restorative materials used during this period, the "extension for retention" concept was introduced by Slagle [41]. This concept focused more on the "anchorage" or retention of the restorative material inside the prepared cavities after careful evaluation of occlusal forces. Also, this concept introduced some secondary features to cavity preparation for increasing the retention of the restorative materials (e.g. grooves, locks and coves). Most of these concepts were acceptable during the last century; however, in the last two decades, most concepts have been modified due to the success of aesthetic restorations and the revolution of adhesive materials.

\section{Minimally invasive concept "Prevention of extension"}

A new conservative philosophy called "minimally invasive dentistry" (MID) is more acceptable nowadays. The main purpose of MID is to achieve as much conservation of dental tissue as possible. MID includes early detection of dental caries, assessment and management of caries-risk, remineralization of early caries lesions, only restoring cavitated lesions, restriction of the excavation to the caries-infected areas and using adhesive-based 
technologies $[42,43]$.

Nowadays, cavity preparation should no longer follow the conventional outline that G.V. Black first introduced or it many other variations. Instead, it should follow the extent of a carious lesion and only eliminate caries-infected tissue with the preservation of both caries-affected and sound tissues [44]. Moreover, significant improvement of amalgam alloys and introduction of bonded amalgam restorations have modified the cavity preparation for amalgam to be more conservative of tooth structure [45]. Also, introduction of conservative cavity designs; such as slot and tunnel preparations, are one of the characteristic features of MID [46]. Furthermore, retentive features changed from macromechanical to micro-mechanical (resin adhesives) and chemical (e.g. resin-modified glass ionomer adhesives) retention [44, 47]. However, toileting of cavities has not changed a lot from Black's principals, some chemical agents (e.g. $2 \%$ chlorhexidine digluconate) are highly recommended because of its antibacterial effects and the possibility to increase the durability of the bond between resin adhesives and tooth structure [48]. Black's convenience form principle is still useful; however, the advances in diagnosis, use of magnification and cavity preparation instrumentation, allow easy access for excavation of infected tissue with maximum preservation of the sound tooth tissue [44]. Finally, MID converts Black's concept from "extension for prevention" to "prevention of extension" $[44,49]$.

\section{Stepwise caries excavation}

The stepwise excavation technique is a method used in removal of caries-infected tissue in deep cavities of asymptomatic vital teeth [5]. In this technique, the caries excavation is performed in two stages with a time lag period [5]. In the first stage, the soft caries should be removed leaving the deepest "firm" layer of caries-infected tissue, which will be covered with a cavity lining and interim filling restorative material [50]. After a certain period of time, "4-12 months" [51], the cavities are re-entered to excavate the residual carious tissue [50]. The rationale of using stepwise excavation is to stop the acute phase of the lesion, reduce the irritation of pulp tissue and giving it the chance for the formation of reparative dentine $[5,50]$. Therefore, using this excavation technique, most likely, reduces the risk of accidental pulp injuries [50].

In 1938, Bodecker [52] was the first author who described the stepwise excavation technique and his histological findings showed the formation of reparative dentine after indirect pulp capping with a temporary filling consisting of zinc-oxide-eugenol lining mixed with "Vialidol-comphorata" and gutta-percha-based material. Many agents have been used in indirect pulp capping such as; zinc-oxide-eugenol [53], calcium hydroxide [54, 55], and mineral trioxide aggregate (MTA) [56]. Several randomized controlled clinical trials showed that using stepwise excavation reduced the chance of pulp exposure during the re-entry phase of treatment $[50,57,58]$. Despite the type of lining, several studies showed that the most important factor of success is to create well-sealed temporary restorations [51, 59-61].

\section{Concept of partial caries removal}

In 2000, an argument was raised about the benefits of "re-opening" of cavities after the first stage of stepwise excavation and this argument was published under the theme "Dentine caries:
Take it or leave it?" [62]. Accordingly, Banerjee and coworkers introduced a new concept of leaving portions of caries-infected dentine after excavation, particularly in deep carious lesions as means to reduce the incidence of accidental pulpinjuries [62-64]. This concept states that: "any grossly softened caries-infecteddentine must be excavated, nevertheless, in deep carious lesions where the inner most layer of dentine, which directly covers the pulp, contains a high concentration of bacteria" provided to create well-sealed restorations $[63,65]$. Banerjee assumed that the remaining portion of a carious lesion is the most superficial layer of "caries-affected" dentine, which can contain some bacteria and partially denatured collagen fibres [74]. This assumption was in agreement with Fusayama's conclusions, who stated that the clinical differentiation between caries-affected and -infected dentine is very difficult to distinguish [6]. Several microbiological studies showed that good sealing of cavities reduces the nutritional supply to the residual bacteria following caries excavation [66-70]. Also, the outcomes of several studies [71-73] (evaluated stepwise excavation) showed that the hardness of the residual dentine had increased during there-entry phase of the treatment, compared to the first stage, which supports Banerjee's "partial caries removal (PCR)"philosophy. A recent clinical trial by Maltz et al. [70] showed that the mean survival rate of restorations following PCR $(91 \%)$ was significantly higher than the rate after stepwise excavation $(69 \%)(\mathrm{p}<0.05)$. Hence, the results of this trial were in total agreement with the PCR concept and the authors have suggested to avoid re-opening of cavities for maximum preservation of pulp vitality.

\section{Atraumatic restorative treatment}

Atraumatic restorative treatment (ART) is an example of the 1-step partial caries excavation technique. The first pilot ART study was performed in the rural areas of Tanzania (due to lack of electricity, which is required for operating complicated dental equipment) and the study was presented at the Tanzanian dental association meeting in 1986 [5]. Later on, similar trials were performed in China, Vietnam, South Africa, Mexico, Ecuador and Brazil [5]. Although, ART was introduced earlier (1986) than the PCR concept, it was approved as one of the caries excavation methods from "Fédération Dentaire Internationale" (FDI) (World Dental Federation) in 2002, due to the popularity of the PCR concept at that time [5]. The ART restorative protocol includes the following steps: (i) slightly widening of the access opening of small cavities using specially designed pyramidal-shaped hand instruments (to improve the accessibility to the carious lesion), (ii) excavation of grossly softened caries-infected dentine using a hand excavator, (iii) caries removal is verified by tactile sensation method using a ball-end explorer, then (iv) cavities are cleaned with chlorhexidine cleaners and restored with high viscosity glass ionomer restorative materials [5]. The outcomes of several long-term follow-up clinical studies (2-6 years) revealed that restorations following ART, showed satisfactory survival rates in both primary $(67-94 \%)$ [7477] and permanent (81-96\%) [78-81] molars.

\section{Conclusion and Clinical Significance}

Conservation of dental hard tissues has become the milestone for any recent caries excavation technique. Furthermore, leaving the caries-infected dentine in some critical regions of the cavity is now regarded as acceptable by many, nowadays, provided that creation of a proper marginal seal can be achieved and maintained. 


\section{References}

[1]. Heymann HO, Swift EJ, Ritter AV, Sturdevant CM (2013) Sturdevant's art and science of Operative Dentistry. In Dental caries: etiology, clinical characteristics, risk assessment, and management. (6th edtn), Elsevier/Mosby, St. Louis, Mo. 41-88.

[2]. Black GV (1936) Black's Work on operative denistry with which his special dental pathology is combined. (7th edtn), Medico Dental Publishing Company, Chicago. 322-335.

[3]. Loesche WJ (1979) Clinical and microbiological aspects of chemotherapeutic agents used according to the specific plaque hypothesis. J Dent Res 58(12): 2404-2412.

[4]. Newbrun E (1983) Cariology. (2nd edtn), Williams \& Wilkins, Baltimore. $1-13$.

[5]. Fejerskov O, Kidd EAM (2009) Dental caries : the disease and its clinical management. (2nd edtn), Blackwell Munksgaard, Oxford, UK. 356-388.

[6]. Fusayama T (1993) A simple pain-free adhesive restorative system by minimal reduction and total etching. Ishiyaku EuroAmerica Inc., Tokyo. 23-45.

[7]. Besinis A, van Noort R, Martin N (2014) Remineralization potential of fully demineralized dentin infiltrated with silica and hydroxyapatite nanoparticles. Dent Mater 30(3): 249-262.

[8]. Niu LN, Zhang W, Pashley DH, Breschi L, Mao J, et al. (2014) Biomimetic remineralization of dentin. Dent Mater 30(1): 77-96

[9]. Nayif MM, Shimada Y, Ichinose S, Tagami J (2010) Nanoleakage of current self-etch adhesives bonded to artificial carious dentin. Am J Dent 23(5): 279-284.

[10]. Ogawa K, Yamashita Y, Ichijo T, Fusayama T (1983) The ultrastructure and hardness of the transparent layer of human carious dentin. J Dent Res 62(1): 7-10.

[11]. Kuboki Y, Liu CF, Fusayama T (1983) Mechanism of differential staining in carious dentin. J Dent Res 62(6): 713-714.

[12]. Fusayama T, Terachima S (1972) Differentiation of two layers of carious dentin by staining. J Dent Res 51(3): 866.

[13]. de Almeida Neves A, Coutinho E, Cardoso MV, Lambrechts P, Van Meerbeek B (2011) Current concepts and techniques for caries excavation and adhesion to residual dentin. J Adhes Dent 13(1): 7-22.

[14]. Sato Y, Fusayama T (1976) Removal of dentin by fuchsin staining. J Dent Res 55(4): 678-683.

[15]. Poole-Wilson DS (1960) Occupational tumours of the bladder. Proc R Soc Med 53(10): 801-814.

[16]. National Cancer Institute (1954-1960) Survey of compounds which have been tested for carcinogenic activity. Public Health Service No.149, Washington DC, USA. 2: 655.

[17]. Yip HK, Stevenson AG, Beeley JA (1994) The specificity of caries detector dyes in cavity preparation. Br Dent J 176(11): 417-421.

[18]. Boston DW, Liao J (2004) Staining of non-carious human coronal dentin by caries dyes. Oper Dent 29(3): 280-286.

[19]. Kidd EA, Joyston-Bechal S, Smith MM, Allan R, Howe L, et al. (1989) The Use of a Caries Detector Dye in Cavity Preparation. Br Dent J 167(4): 132-134.

[20]. Iwami Y, Shimizu A, Narimatsu M, Kinomoto Y, Ebisu S (2005) The relationship between the color of carious dentin stained with a caries detector dye and bacterial infection. Oper Dent 30(1): 83-89.

[21]. Hosoya Y, Taguchi T, Tay FR (2007) Evaluation of a new caries detecting dye for primary and permanent carious dentin. J Dent 35(2): 137-143.

[22]. Kinoshita J, Shinomiya H, Itoh K, Matsumoto K (2007) Light intensity evaluation of laser-induced fluorescence after caries removal using an experimental caries staining agent. Dent Mater J 26(3): 307-311.

[23]. Black GV (1908) A work on Operative Dentistry. Medico-Dental Publishing Company, Chicago.

[24]. Mount GJ, Hume WR (1998) A new cavity classification. Aust Dent J 43(3): 153-159.

[25]. Mount GJ, Tyas JM, Duke ES, Hume WR, Lasfargues JJ, et al. (2006) A proposal for a new classification of lesions of exposed tooth surfaces. Int Dent J 56(2): 82-91.

[26]. Pitts N (2004) "ICDAS"-an international system for caries detection and assessment being developed to facilitate caries epidemiology, research and appropriate clinical management. Community Dent Health 21(3): 193-198.

[27]. Ismail AI, Sohn W, Tellez M, Amaya A, Sen A, et al. (2007) The International Caries Detection and Assessment System (ICDAS): an integrated system for measuring dental caries. Community Dent Oral Epidemiol 35(3): 170-178.

[28]. Tikhonova SM, Feine JS, Pustavoitava NN, Allison PJ (2014) Reproducibility and diagnostic outcomes of two visual-tactile criteria used by dentists to assess caries lesion activity: a cross-over study. Caries Res 48(2): 126-136.

[29]. Ricketts D, Bartlett DW (2011) Advanced Operative Dentistry: a practi- cal approach. In Management of dental caries. Churchill Livingstone, New York. 1-13.

[30]. Ekstrand KR, Ricketts DN, Kidd EA (1997) Reproducibility and accuracy of three methods for assessment of demineralization depth of the occlusal surface: an in vitro examination. Caries Res 31(3): 224-231.

[31]. Lussi A, Imwinkelried S, Pitts N, Longbottom C, Reich E (1999) Performance and reproducibility of a laser fluorescence system for detection of occlusal caries in vitro. Caries Res 33(4): 261-266.

[32]. International Caries Detection and Assessment System (ICDAS) co-ordinating committee. ICDAS-II. (2014) [cited 1/3/2014]; Available from: https://www.icdas.org/home.

[33]. Webb MH (1883) Notes on Operative Dentistry. S.S. White Manufacturing Co., Philadelphia. 72-88.

[34]. Black GV (1891) The managment of enamel margins. Dental Cosmos 33 85-100.

[35]. Black GV, Black AD (1924) A work on special dental pathology : devoted to the diseases and treatment of the investing tissues of the teeth and the dental pulp, including the sequelae of the death of the pulp, also, systematic effects of mouth infections, oral prophylaxis and mouth hygiene. (3rd edtn), Medico-Dental Publishing Co., Chicago. 204-207.

[36]. Trallero MM (1900) Treatment of dental caries. Dental Cosmos 42(10): 1011-1013.

[37]. Meyer JM (1903) Principles for cavity preparation. Dental Cosmos 45: $187-$ 188.

[38]. Black AD (1909) Cavity preparation, based on the pathology of dental caries. Dental Cosmos 51: 957-962.

[39]. Hofheinz RH (1902) Extension for Prevention. Dental Cosmos 44: 914 919.

[40]. Noyes FB (1904) Extension for prevention: A study of conditions in the mouth. Dental Cosmos 46: 832-837.

[41]. Slagle CE (1904) The Fundamental Principles of Extension in Approximal Cavities in Bicuspids and Molars. Dental Cosmos 46: 443-445.

[42]. Ericson D (2007) The concept of minimally invasive dentistry. Dent Update 34(1): 9-10.

[43]. Frencken JE, Peters MC, Manton DJ, Leal SC, Gordan VV, et al. (2012) Minimal intervention dentistry for managing dental caries - a review: report of a FDI task group. Int Dent J 62(5): 223-243.

[44]. Peters MC, McLean ME (2000) Minimally invasive operative care. I. Minimal intervention and concepts for minimally invasive cavity preparations. J Adhes Dent 3(1): 7-16.

[45]. Bonsor SJ (2011) Bonded amalgams and their use in clinical practice. Dent Update 38(4): 222-224.

[46]. Peters MC, McLean ME (2000) Minimally invasive operative care. II. Contemporary techniques and materials: an overview. J Adhes Dent 3(1): 17-31.

[47]. Mitra SB, Lee CY, Bui HT, Tantbirojn D, Rusin RP (2009) Long-term adhesion and mechanism of bonding of a paste-liquid resin-modified glassionomer. Dent Mater 25(4): 459-466.

[48]. Hiraishi N, Yiu CK, King NM, Tay FR (2009) Effect of 2\% chlorhexidine on dentin microtensile bond strengths and nanoleakage of luting cements. J Dent 37(6): 440-448

[49]. Burke FJ (2003) From extension for prevention to prevention of extension: (minimal intervention dentistry). Dent Update 30(9): 492-498.

[50]. Leksell E, Ridell K, Cvek M, Mejare I (1996) Pulp exposure after stepwise versus direct complete excavation of deep carious lesions in young posterior permanent teeth. Endod Dent Traumatol 12(4): 192-196.

[51]. Hilton TJ (2009) Keys to clinical success with pulp capping: a review of the literature. Oper Dent 34(5): 615-625.

[52]. Bodecker CF (1938) Histologic evidence of the benefits of temporary fillings and successful pulp capping of deciduous teeth. J Am Dent Assoc 25(5): 777-788.

[53]. Kerkhove BC Jr, Herman SC, Klein AI, McDonald RE (1967) A clinical and television densitometric evaluation of the indirect pulp capping technique. J Dent Child 34(3): 192-201.

[54]. Maltz M, de Oliveira EF, Fontanella V, Bianchi R (2002) A clinical, microbiologic, and radiographic study of deep caries lesions after incomplete caries removal. Quintessence Int 33(2): 151-159.

[55]. Casagrande L, Bento LW, Dalpian DM, Garcia-Godoy F, de Araujo FB (2010) Indirect pulp treatment in primary teeth: 4-year results. Am J Dent 23(1): 34-38.

[56]. Leye Benoist F, Gaye Ndiaye F, Kane AW, Benoist HM, Farge P (2012) Evaluation of mineral trioxide aggregate (MTA) versus calcium hydroxide cement $\left(\mathrm{Dycal}^{\circ}\right)$ in the formation of a dentine bridge: a randomised controlled trial. Int Dent J 62(1): 33-39.

[57]. Magnusson BO, Sundell SO (1977) Stepwise excavation of deep carious lesions in primary molars. J Int Assoc Dent Child 8(2): 36-40.

[58]. Bjorndal L, Reit C, Bruun G, Markvart M, Kjaeldgaard M, et al. (2010) Treatment of deep caries lesions in adults: randomized clinical trials comparing stepwise vs. direct complete excavation, and direct pulp capping vs. 
partial pulpotomy. Eur J Oral Sci 118(3): 290-297.

[59]. Handelman SL, Washburn F, Wopperer P (1976) Two-year report of sealant effect on bacteria in dental caries. J Am Dent Assoc 93(5): 967-970.

[60]. Oliveira EF, Carminatti G, Fontanella V, Maltz M (2006) The monitoring of deep caries lesions after incomplete dentine caries removal: results after 14-18 months. Clin Oral Investig 10(2): 134-139.

[61]. Franzon R, Casagrande L, Pinto AS, Garcia-Godoy F, Maltz M, et al. (2007) Clinical and radiographic evaluation of indirect pulp treatment in primary molars: 36 months follow-up. Am J Dent 20(3): 189-192.

[62]. Banerjee A, Watson TF, Kidd EA (2000) Dentine caries: take it or leave it? Dent Update 27(6): 272-276.

[63]. Banerjee A (2013) Minimal intervention dentistry: part 7. Minimally invasive operative caries management: rationale and techniques. $\mathrm{Br}$ Dent J 214(3): 107-111.

[64]. Bjorndal L, Kidd EA (2005) The treatment of deep dentine caries lesions. Dent Update 32(7): 402-413.

[65]. Thompson V, Craig RG, Curro FA, Green WS, Ship JA (2008) Treatment of deep carious lesions by complete excavation or partial removal: a critical review. J Am Dent Assoc 139(6): 705-712.

[66]. Foley J, Evans D, Blackwell A (2004) Partial caries removal and cariostatic materials in carious primary molar teeth: a randomised controlled clinical trial. Br Dent J 197(11): 697-701.

[67]. Kidd EA (2004) How 'clean' must a cavity be before restoration? Caries Res 38(3): 305-313

[68]. Borczyk D, Piatowska D, Krzeminski Z (2006) An in vitro study of affected dentin as a risk factor for the development of secondary caries. Caries Res 40(1): 47-51.

[69]. Maltz M, Henz SL, de Oliveira EF, Jardim JJ (2012) Conventional caries removal and sealed caries in permanent teeth: a microbiological evaluation. J Dent 40(9): 776-782

[70]. Maltz M, Garcia R, Jardim JJ, de Paula LM, Yamaguti PM, et al. (2012) Randomized trial of partial vs. stepwise caries removal: 3-year follow-up. J Dent Res 91(11): 1026-1031.
[71]. Bjorndal L, Larsen T (2000) Changes in the cultivable flora in deep carious lesions following a stepwise excavation procedure. Caries Res 34(6): 502 508.

[72]. Maltz M, Oliveira EF, Fontanella V, Carminatti G (2007) Deep caries lesions after incomplete dentine caries removal: 40-month follow-up study. Caries Res 41(6): 493-496.

[73]. Hayashi M, Fujitani M, Yamaki C, Momoi Y (2011) Ways of enhancing pulp preservation by stepwise excavation--a systematic review. J Dent 39(2): 95-107.

[74]. Yee R (2001) An ART field study in western Nepal. Int Dent J 51(2): 103108.

[75]. Taifour D, Frencken JE, Beiruti N, van 't Hof MA, Truin GJ (2002) Effectiveness of glass-ionomer (ART) and amalgam restorations in the deciduous dentition: results after 3 years. Caries Res 36(6): 437-444.

[76]. Ibiyemi O, Bankole OO, Oke GA (2011) Assessment of Atraumatic Restorative Treatment (ART) on the permanent dentition in a primary care setting in Nigeria. Int Dent J 61(1): 2-6.

[77]. Ersin NK, Candan U, Aykut A, Oncag O, Eronat C, et al. (2006) A clinical evaluation of resin-based composite and glass ionomer cement restorations placed in primary teeth using the ART approach: results at 24 months. J Am Dent Assoc 137(11): 1529-1536.

[78]. Ho TF, Smales RJ, Fang DT (1999) A 2-year clinical study of two glass ionomer cements used in the atraumatic restorative treatment (ART) technique. Community Dent Oral Epidemiol 27(3): 195-201.

[79]. Lo EC, Holmgren CJ, Hu D, van Palenstein Helderman W (2007) Six-year follow up of atraumatic restorative treatment restorations placed in Chinese school children. Community Dent Oral Epidemiol 35(5): 387-392.

[80]. Zanata RL, Fagundes TC, Freitas MC, Lauris JR, Navarro MF (2011) Tenyear survival of ART restorations in permanent posterior teeth. Clin Oral Investig 15(2): 265-271.

[81]. Frencken JE, Taifour D, van 't Hof MA (2006) Survival of ART and amalgam restorations in permanent teeth of children after 6.3 years. J Dent Res 85(7): 622-626. 